$\xi=-1$

\title{
Level and Capacity Assessment of Technological Development of Enterprise
}

\author{
S.A. Mikaeva, A.S. Mikayeva \\ MIREA - Russian Technological University, Moscow, Russia
}

\begin{abstract}
This article assesses the technological level and potential of technological development of an enterprise on the basis of a methodical approach. The essence of this approach is to build a composite indicator of the object being evaluated by determining its key components. First, there is a process of decomposing the summary indicator in order to determine the quantitative indicators of its constituent elements, and then, aggregating the obtained values into a composite index in order to obtain a generalized assessment.
\end{abstract}

Keyword: production, potential, composite, technological, indicators.

\section{Introduction}

In modern conditions, as the experience of economically developed countries shows, the competitiveness of economy can be ensured. This is done first of all, through advanced technological development. All developed countries are actively developing advanced technologies, introducing them into production and gradually "pulling up" the technological level of related industries[1]. Technological development is of particular importance for enterprises of those activities that define technical and technological level of other industries and activities. Such activities are basic in enhancing innovation development, which is currently becoming a priority for the Russian economy.

However, the current level of such basic industries in Russian economy (among them are instrument making, mechanical engineering, machine tool building, etc.) is significantly inferior to the advanced world level. The products of Russian enterprises mainly occupy weak competitive positions (both in the world and in the domestic market). Streamlining and regulating technological development contributes to improving the competitiveness of an enterprise, increasing the efficiency of funds allocated for development, reducing time to achieving development goals. Thus, technological development is a controlled process of technological changes in an enterprise, the result of which is creation of new opportunities for an economic entity [2]. Management of technological development of the enterprise should:

- be implemented in accordance with the technological policy pursued by the company;

- be implemented as part of a technology development strategy.

The selection and formation of a technological development strategy should be carried out using a variety of analytical procedures, the main of which is assessment of technological level and potential of technological development of the enterprise. It should be noted that meaning of technological development potential as an economic category is not only to assess the potential of an economic entity as a whole, but also to facilitate selection of a particular direction and variant of technological development of the enterprise and formation on this basis of its effective technological policy.

\section{Research Method}

Many of the traditionally used indicators in the context of changing trends in economic development, and transition to an economy based on knowledge, has become uninformative, not fully reflecting the current factors of the economic dynamics of enterprises.

For example, for modern enterprises of instrument-making, creation of competitive products is impossible without use of modern computer-aided design technologies, technological preparation of production and actual production processes, modern technologies for organizing activities, including the promotion and marketing of products. Therefore, as a criterion of technological development level of an enterprise, indicators characterizing the level of informatization and computerization of organizational processes should be used [3].

The desire to use modern technologies at all stages of the product life cycle should be correlated with feasibility of technological changes. In this connection there is a need to assess the potential of technological development, which essentially determines the possible limits of transformation processes in an enterprise.

To assess the technological level and potential of technological development of an enterprise, it seems appropriate to use a methodical approach based on the use of the Harrington "function of desirability" [4, 5], the difference of which is lack of expert assessments, which virtually eliminates the influence of subjective factor .

Method of this approach consists in building a summary indicator of the object being evaluated (CIi), which can be sequentially decomposed into its components. Moreover, the process of decomposing the summary indicator first takes place in order to determine the quantitative indicators of its constituent elements, and then aggregate the obtained values into a composite index in order to obtain a generalized assessment. 
Composite index of the estimated object is calculated as the geometric average of values of selected indicators. In the proposed methodological approach, an adapted version of the Harrington method is used. The choice of geometric mean is due to the fact that the composite index is a generalizing characteristic, and it is this property that average value has; the choice of the geometric type of the average is explained by the fact that it is in its essence the most adequate to the problem being solved.
In our case, the main components of the estimated parameters

$(\mathrm{Mj})$ are:

1. Technological level of the enterprise - the technological level of the main and auxiliary production processes (M11), which for the instrument-making enterprises are considered as unified at all stages of the life cycle (design-design-production) and technological level of management processes (M12);

Table 1 - Indicators of the technological level of the enterprise (based on the data of the NPO "LIT")

\begin{tabular}{|c|c|c|}
\hline \multicolumn{3}{|c|}{ Technological level of the enterprise } \\
\hline Components & Name of the indicator Value & Indicator \\
\hline 1 & 2 & 3 \\
\hline $\begin{array}{l}\text { Main and auxiliary } \\
\text { manufacturing } \\
\text { processes }\end{array}$ & $\begin{array}{l}\text { 1. the coefficient of automation design engineering } \\
\text { 2. coefficient of automation of production processes } \\
\text { 3. the share of CNC machines in the total equipment park } \\
\text { 4. coefficient of validity of automated equipment } \\
\text { 5. coefficient of computer equipment of work of designers and technologists } \\
\text { 6. share of parametric 3D modeling software }\end{array}$ & $\begin{array}{l}0,34 \\
0,42 \\
0,10 \\
0,65 \\
0,75 \\
0,15\end{array}$ \\
\hline $\begin{array}{l}\text { Managerial } \\
\text { processes }\end{array}$ & $\begin{array}{l}\text { 1. the proportion of employees AUP using } \\
\text { personal computers } \\
\text { 2. PC update rate in AUP units } \\
\text { 3. share of high-speed facilities } \\
\text { information in the park of infrared equipment } \\
\text { 4. share of commercial interactions carried out with the help of ICT in the total volume of transactions (purchases / } \\
\text { sales) }\end{array}$ & $\begin{array}{l}0,78 \\
0,37 \\
0,20 \\
0,38\end{array}$ \\
\hline
\end{tabular}

1.

2.1.

2.2 .

2.3 .
Technological development process: personnel potential of the enterprise $\left(\mathrm{M}_{21}\right)$; Innovation potential $\left(\mathrm{M}_{22}\right)$; financial and investment potential $\left(\mathrm{M}_{23}\right)$

\section{Results and Analysis}

Each of the components was characterized by a set of indicators (expressed in coefficients), which are presented in Tables 1 and 2.

Table 2 - Indicators of the potential of technological development of the enterprise (based on the data of NPO LIT)

\begin{tabular}{|c|c|c|}
\hline \multicolumn{3}{|c|}{ Potential technological development } \\
\hline Components & Name of the indicator & $\begin{array}{l}\text { Value } \\
\text { indicator }\end{array}$ \\
\hline 4 & 5 & 6 \\
\hline $\begin{array}{l}\text { HR } \\
\text { potential }\end{array}$ & $\begin{array}{l}\text { 1. the share of employees engaged in research, development, innovation } \\
\text { 2. proportion of employees regularly undergoing advanced training } \\
\text { 3. the share of highly qualified workers in the total number of engineering and technical workers } \\
\text { 4. the coefficient of consistency of highly qualified staff }\end{array}$ & $\begin{array}{l}0,30 \\
0,42 \\
0,33 \\
0,70\end{array}$ \\
\hline $\begin{array}{l}\text { Innovative } \\
\text { potential }\end{array}$ & $\begin{array}{l}\text { 1. the share of innovative intangible assets in the value of all intangible assets } \\
\text { 2. share of technological innovations in the total amount of innovation activity } \\
\text { 3. the share of R \& D costs in investments } \\
\text { 4. the share of innovative goods, works, services in the total activity of the enterprise }\end{array}$ & $\begin{array}{l}0,51 \\
0,30 \\
0,17 \\
0,32\end{array}$ \\
\hline $\begin{array}{l}\text { Financial and } \\
\text { investment potential }\end{array}$ & $\begin{array}{l}\text { 1. coefficient of financial independence } \\
\text { 2. liquidity ratios: } \\
\text { - current; } \\
\text { - fast; } \\
\text { - absolute. } \\
\text { 3. the share of investment in new non-financial assets }\end{array}$ & $\begin{array}{l}0,59 \\
1,4 \\
0,92 \\
0,35 \\
0,43\end{array}$ \\
\hline
\end{tabular}

In this case, the number of indicators may be different. An increase in the number of indicators will make it possible to increase the accuracy of the measurement of the corresponding parameter, and hence, to increase the accuracy of the conclusions obtained on their basis.
Based on the actual values of the indicators presented in gr. 3 tables 1 and 2 were calculated indices of all components of the estimated parameters $\mathrm{i}$ and composite indices:

$$
\text { ИМ }_{11}=\sqrt[6]{0,34 \cdot 0,42 \cdot 0,10 \cdot 0,65 \cdot 0,75 \cdot 0,15}=0,318505
$$




$$
\begin{aligned}
& \mathrm{UM}_{12}=\sqrt[4]{0,78 \cdot 0,37 \cdot 0,20 \cdot 0,38}=0,3848591 \\
& \mathrm{UM}_{21}=\sqrt[4]{0,30 \cdot 0,42 \cdot 0,33 \cdot 0,70}=0,41304 \\
& \mathrm{UM}_{22}=\sqrt[4]{0,51 \cdot 0,30 \cdot 0,17 \cdot 0,32}=0,30204 \\
& \mathrm{UM}_{23}=\sqrt[3]{0,59 \cdot 0,48 \cdot 0,43}=0,4956 ; \\
& \mathrm{C} \mathrm{U}_{\mathrm{M} 1}=\sqrt[2]{0,318505 \cdot 0,3848591}=0,3501 \\
& \mathrm{CU}_{\mathrm{M} 2}=\sqrt[3]{0,41304 \cdot 0,30204 \cdot 0,4956}=0,3954 .
\end{aligned}
$$

Evaluation of the obtained index values is done on the scale of Harrington desirability function, which ranges from 0 to 1 as following: [0 - 0.2] - "very bad", [0.2 - 0.37] - " bad ", [0.37 $0.63]$-" satisfactory ", [0.63 - 0.8] -“ good ”, [0.8 - 1] -" very good". Interval interpretation is different for evaluating level indicators: very low level, low level, medium level, high level, very high level.

\section{Conclusion}

Evaluation of the obtained value of composite technological level of enterprise allows us to conclude that the enterprise under consideration is characterized by a close to average level of technological development, however, the value is closer to the lower limit. Somewhat higher is the level of technological development potential, the composite index of which falls into the "average" interval.

At the same time, attention is drawn to the fact that the main and auxiliary production processes of the enterprise are the most technologically "weak" with a sufficiently higher level of the financial and investment potential of the enterprise. This indicates that the available funds are spent inefficiently, the policy of technological change is not justified.

A higher level of development potential indicates the need to enhance its effective use, expand the internal system of technological development, otherwise the potential will remain unclaimed by production.

\section{References}

[1] Rogova V.A. The Russian Technological Journal, 2018. V. 6 No. 4. P. 105-116.

[2] Mikayeva A.S. The potential of technological development of the enterprise and approaches to its assessment // Journal-book "Entrepreneurship", Moscow, 2013. - №4, p. 51-58.

[3] Orlova E.R., Mikayeva A.S. A tool for quantifying the level and potential of the technological development of an instrument making enterprise // Today and Tomorrow of the Russian Economy. - Moscow, 2014. - № 64. - p. 78-82.

[4] Mikayeva, A.S. Strategic management of technological development of instrument-making enterprises: monograph / A.S. Mikayev. - Moscow: RUSAINS, 2018. - 114 p.

[5] Mikayeva A.S. Tools for developing a strategy for technological development of enterprises of basic industries of the modern economy (on the example of instrument-making): dissertation for the degree of candidate of economic sciences: 08.00.05: defended 10.22.2013: approved. 02/10/2014. - M., 2013. - 146 p. 